\title{
Development of End Plug Welding Technique for SFR Fuel Rod Fabrication
}

\author{
Jung Won Lee, Jong Hwan Kim, Ki Hwan Kim, Jeong Yong Park, and Sung Ho Kim
}

Next Generation Fuel Division, Korea Atomic Energy Research Institute, 111 Daedeok-daero 989 Beon-gil, Yuseong-gu, Daejeon 305-353, Republic of Korea

Correspondence should be addressed to Jong Hwan Kim; jhk9@kaeri.re.kr

Received 23 May 2016; Accepted 28 August 2016

Academic Editor: Waclaw Gudowski

Copyright (C) 2016 Jung Won Lee et al. This is an open access article distributed under the Creative Commons Attribution License, which permits unrestricted use, distribution, and reproduction in any medium, provided the original work is properly cited.

\begin{abstract}
In Korea, $\mathrm{R} \& \mathrm{D}$ on a sodium-cooled fast reactor (SFR) was begun in 1997, as one of the national long-term nuclear R\&D programs. As one fuel option for a prototype SFR, a metallic fuel, U-Zr alloy fuel, was selected and is currently being developed. For the fabrication of SFR metallic fuel rods, the end plug welding is a crucial process. The sealing of the end plug to the cladding tube should be hermetically perfect to prevent a leakage of fission gases and to maintain a good reactor performance. In this study, the welding technique, welding equipment, welding conditions, and parameters were developed for the end plug welding of SFR metallic fuel rods. A gas tungsten arc welding (GTAW) technique was adopted and the welding joint design was developed. In addition, the optimal welding conditions and parameters were established. Based on the establishment of the welding conditions, the GTAW technique was qualified for the end plug welding of SFR metallic fuel rods.
\end{abstract}

\section{Introduction}

The generation IV (Gen-IV) program was started by eleven countries in 2000 for the development of an innovative nuclear energy system along with its goals, safety, economics, resource utilization, waste management, proliferation resistance, and physical protection (PR and PP) [1]. Among the six selected systems within the Gen-IV program is a sodiumcooled fast reactor (SFR). It is expected to become available for commercial introduction in around 2030 [2]. In Korea, the R\&D on a SFR began in 1997, as one of the national long-term nuclear R\&D programs. As the fuel for a prototype SFR, a metallic fuel, U-Zr alloy, was selected and is being developed. In addition, international collaborative research is also under way on U-TRU-Zr fuel developments with the closed fuel cycle of the full actinide recycling, within the Advanced Fuel Project for the international generation IV (Gen-IV) SFR $[2,3]$. For the fabrication of SFR metallic fuel rods, the end plug welding is a crucial process $[4,5]$. The sealing of the end plug to the cladding tube should be hermetically perfect to prevent the leakage of fission gases and maintain a good reactor performance [6].
In this study, the gas tungsten arc welding (GTAW) technique was chosen for the end plug welding, and the welding joint design, the welding conditions, and parameters were developed. In addition, the optimal welding conditions and parameters were established. To prove the end plug weld integrity, the qualification test of the end plug welding for SFR metallic fuel rods was carried out based on the developed welding technique, welding equipment, welding conditions, and parameters. Through the qualification test, the end plug welding process for SFR metallic fuel rod fabrication was successfully established.

\section{Features of SFR Metallic Fue}

The specifications and dimensions of the SFR metallic fuel assembly are shown in Figure 1, which is under development at the Korea Atomic Energy Research Institute (KAERI). In the current SFR design development, U-Zr and U-TRU-Zr metallic fuel are used for the early and later stages of reactor operation, respectively. TRU (transuranic elements and transuranium elements) means radioactive elements with atomic numbers higher than that of uranium in the periodic 

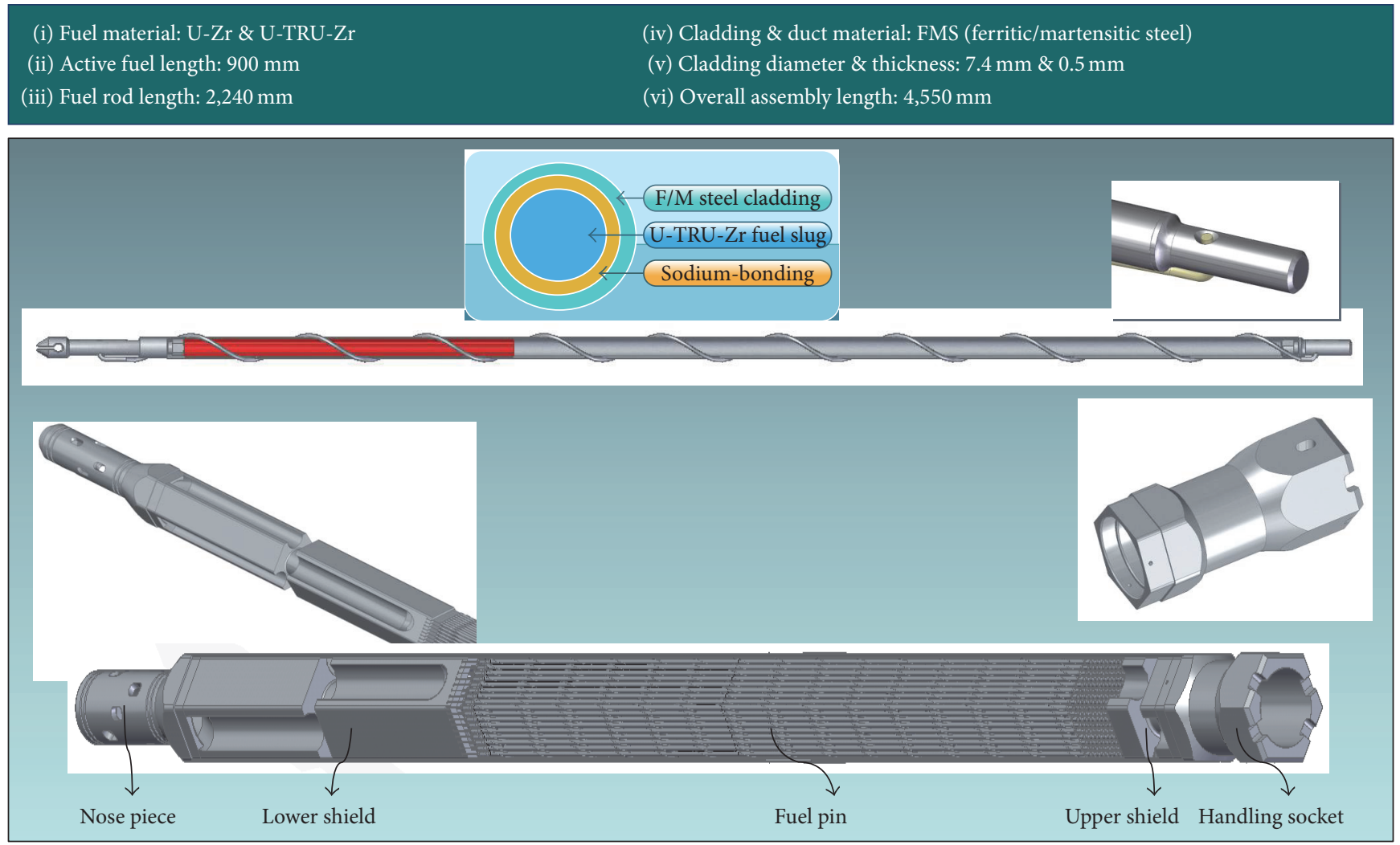

FIGURE 1: SFR metallic fuel.

TABLE 1: Chemical composition of HT9 (\%).

\begin{tabular}{lcccccccccccc}
\hline $\mathrm{C}$ & $\mathrm{Si}$ & $\mathrm{Ni}$ & $\mathrm{Mn}$ & $\mathrm{Cr}$ & $\mathrm{Mo}$ & $\mathrm{V}$ & $\mathrm{Nb}$ & $\mathrm{W}$ & $\mathrm{Al}$ & $\mathrm{Ti}$ & $\mathrm{B}$ \\
\hline 0.2 & 0.25 & 0.5 & 0.6 & 12 & 1.0 & 0.3 & $<0.05$ & 0.5 & $<0.05$ & 0.04 & 0.01 \\
\hline
\end{tabular}

table of elements like neptunium, plutonium, americium, and others. TRU recovered from nuclear fuels irradiated in the commercial nuclear power plant by reprocessing is used for SFR to solve the problem of used nuclear fuel accumulation in the commercial nuclear power plant and increase the utilization of uranium resources. The composition of the fuel is $\mathrm{U}-20 \% \mathrm{TRU}-10 \% \mathrm{Zr}$ for the closed fuel cycle and U-10\% Zr for the prototype reactor. As shown in this figure, a fuel assembly is composed of a nose piece and a handling socket in the end and a duct in the middle part, which contains 217 fuel rods assembled inside it [7]. Each fuel rod has a lower end plug, a fuel slug, an upper gas plenum, and an upper end plug as shown in Figure 1. The outside of the fuel rod is wrapped with a wire to maintain a gap between neighboring fuel rods. Inside the fuel rod, the gap between the fuel slug and fuel cladding is filled with sodium (Na). The environment of a SFR core is more severe than that of a PWR (Pressurized Water Reactor) core. Thus, high-chromium (9$12 \% \mathrm{Cr}$ ) ferritic/martensitic steels were considered for a SFR core application, because of their excellent thermal properties and irradiation resistance relative to austenitic stainless steels [8]. Sandvik HT9 was chosen as the material for SFR fuel rod components, cladding tube, end plug, and wrapping wire.
Table 1 shows the chemical composition of HT9. In principle, a closed fuel cycle is based on the recycling of spent fuel discharged from a pressurized water reactor, which means the handling of high radioactive materials. Since americium $(\mathrm{Am})$ is a strong gamma emitter and curium $(\mathrm{Cm})$ is a high neutron emitter, the fabrication of TRU bearing metallic fuel needs to be performed in a remote control fabrication facility in a shielded hot-cell with sufficient radiation protection. Moreover, all fabrication works should be performed in an inert atmosphere, because of the high reactivity of the handling materials such as uranium $(\mathrm{U})$, plutonium $(\mathrm{Pu})$, and sodium $(\mathrm{Na})$ metals.

\section{End Plug Welding}

End plug welding is the most critical process in the manufacturing of nuclear fuel. In general, the welding techniques are divided into two welding methods, fusion and solid state welding. Fusion welding involves the melting of the materials to be joined, but a solid state welding does not. There are many commercialized welding techniques such as GTAW, electron beam welding (EBW), and laser beam welding (LBW) as fusion welding, as well as resistance upset 


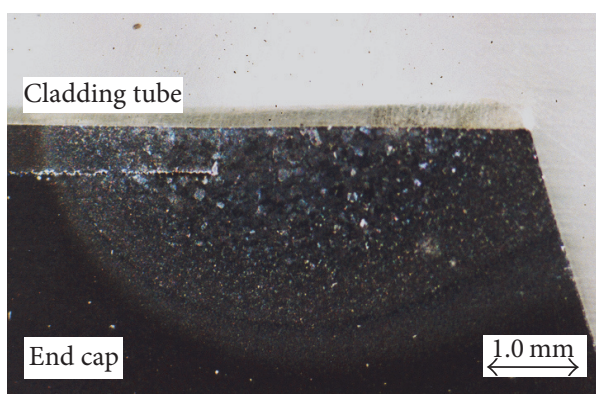

(a) Weld zone by GTAW

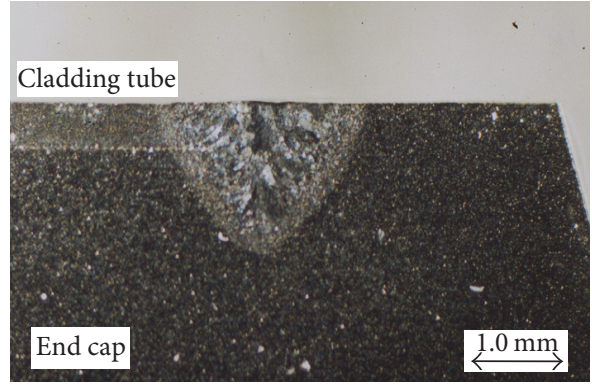

(b) Weld zone by LBW

Figure 2: Microstructures of weld zone in fusion welding.

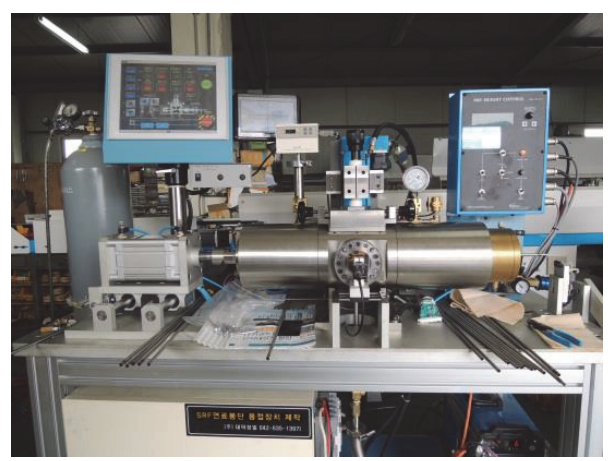

Figure 3: Photograph of the GTAW system for end plug welding.

butt welding, ultrasonic welding, and friction welding as solid state welding. Among them, resistance upset butt welding is now used for the end plug welding of the pressurized water reactor (PWR) fuel elements and pressurized heavy water reactor (PHWR) fuel rods on a commercial basis. During welding, a microstructural change occurs in the fusion zone and Heat Affected Zone (HAZ), which affects its mechanical properties. The fusion zone has experienced the highest temperature and highest cooling rates, while the HAZ farthest away from the fusion zone has had the lowest temperature and lowest cooling rate. This means that a weld zone will have a larger variety of microstructures. The extent of the fusion zones and HAZ varies with the amount of heat generated by the welding method. EBW and LBW give a highly concentrated but limited amount of heat, resulting in a small HAZ. GTAW has a lower heat input and consequently results in a larger HAZ. Figure 2 shows the typical weld microstructures of Zircaloy-4 end cap welding created using GTAW and LBW. In addition, the extent of fusion and HAZ is related to the thermal diffusivity of the base material. The higher the thermal diffusivity is, the higher the cooling rate is. Thus, the end plug welding method should be selected and developed under consideration of the weldability, weld joint design, production efficiency, and so on. In the case of GTAW, the equipment is simple and the welding procedures are not complicated, but the weld defects like an undercut or pin-hole occasionally occur due to the features of the fusion welding.
3.1. GTAW System. GTAW melts the weld joint by an electric arc generated between the tip of a tungsten electrode and the weld joint. A GTAW system for the end plug welding was developed, as shown in Figure 3.

It is composed of a GTAW welder (Model Maxstar 200DX, Miller), a welding chamber, and an arc height controller (Model HAS-01-A-1, Hangil Industry Co.). End plug welding is carried out in a He gas atmosphere confined in a welding chamber. The welding chamber accommodates the weld joint and is evacuated to remove air gas and is back filled with high purity (99.999\%) He gas to fill the inner space of the fuel rod. A welding torch containing a welding electrode is located on top of the welding chamber. The weld joint is positioned directly under the welding electrode as shown in Figure 4. The cladding tube plugged with an end plug is rotated, and welding is conducted by the arc generated between the cladding tube and welding electrode, which is the welding position PA/1G. A CCTV camera was used to monitor the alignment of the weld joint and the arc during the welding process. In addition, an arc height controller (Model HAS-01-A-1, Hangil Industry Co.) was introduced to adjust the gap between the cladding tube and the tip of the welding electrode.

3.2. Weld Joint Design. There are many weld joint designs for fuel rod end plug welding according to their requirements. Figures 5 and 6 show two typical weld joint designs for fusion 


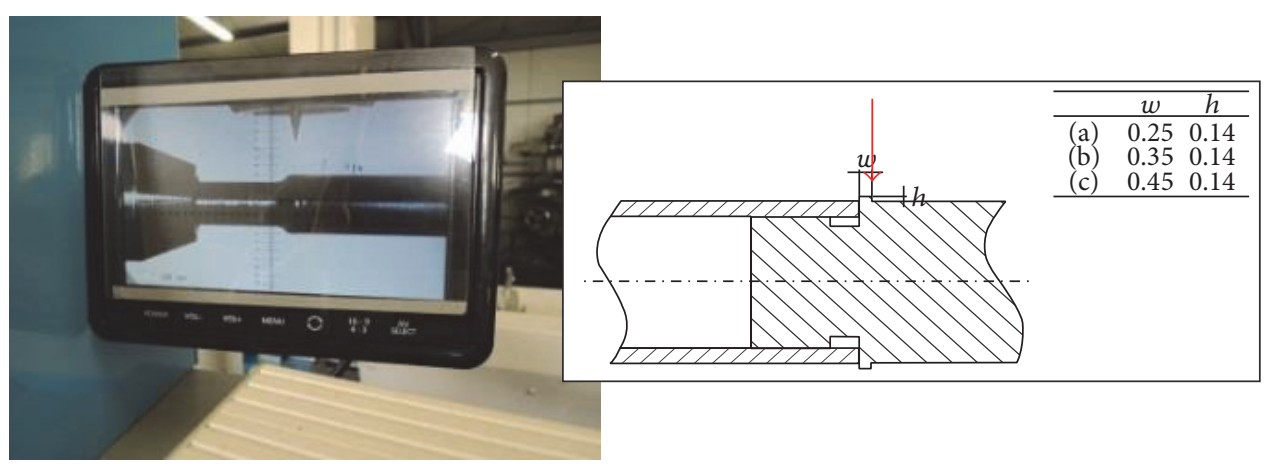

FIGURE 4: Alignment between weld joint and electrode.

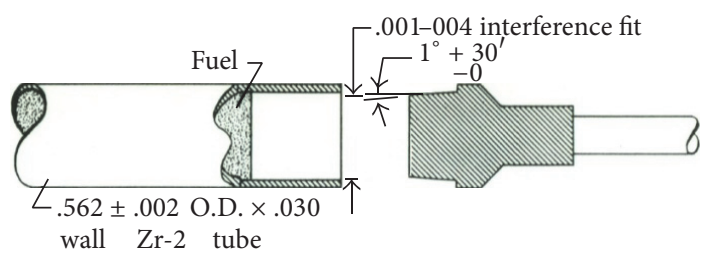

FIGURE 5: Weld joint designs for fusion welding (GTAW and LBW) [5].
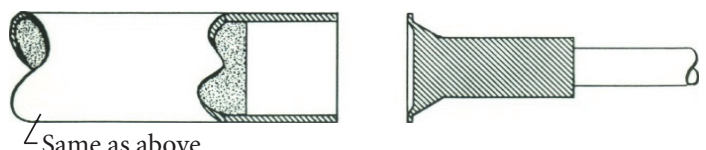

Figure 6: Weld joint designs for solid state welding (RW) [5].

welding and solid state welding $[4,5]$. Basically, the end plug welding is an autogenous welding process, which is carried out without the addition of filler metal because the cladding tube wall thickness is very thin, at around $0.5 \mathrm{~mm}$. Figure 5 shows an example of the joint design for fusion welding such as GTAW, electron beam welding (EBW), and laser beam welding (LBW), resulting in the weld shape after the welding shown in Figure 2. In addition, Figure 6 shows an example of the weld joint design for solid state welding such as resistance upset butt welding, resulting in the weld shape after welding shown in Figure 7.

To establish the optimum end plug welding parameters for the fabrication of SFR metallic fuel rods, a series of welding experiments were conducted with cladding tube material HT9, ferritic/martensitic stainless steel. The fusion weld joint design (Figure 8) was used to join an end plug to a cladding tube for SFR fuel rod fabrication. The bottom of the end plug inserted into the inside of the cladding tube has a space to accommodate a shielding gas during welding. The weld shape after welding is rounded at the tip of the fuel rod, as shown in Figure 9.

3.3. Weld Joint Design Improvement. As shown in Figure 10, some serious weld defects were found during end plug welding for the end closure of the SFR fuel rod. The weld shape was irregular and unsteady, not meeting the dimension requirements of the fuel rod. The cause of these defects was considered to be the difficulty in the alignment of the weld joint and electrode, as shown in Figure 4. Figure 11 shows the dimensions of the original end plug to be welded. As shown in this figure, the weld step to be welded is too small, $0.68 \pm 0.05 \mathrm{~mm}$, to weld using GTAW.

To improve the weld quality of the end closure weld, four kinds of weld joint designs were developed in variation with the dimensions of the end plugs and tested with the established welding parameters. Among them, the improved design, as shown in Figure 12, was optimal because no weld defect was found and the weld shape satisfied the weld dimension requirements as shown in Figure 13. Thus the improved design was finally selected for the end plug welding of a SFR fuel rod. In this design, the weld step to be welded is enlarged to $4 \pm 0.05 \mathrm{~mm}$, which simplified alignment of the weld joint and electrode.

3.4. End Plug Welding by GTAW. On the basis of an improved end plug design, the performance tests were conducted for the establishment of the optimal end plug welding parameters to fabricate a SFR metallic fuel rod, as shown in Table 2. These welding parameters were set up with a GTAW welder (Model Maxstar 200DX, Miller) and an arc height controller (Model HAS-01-A-1, Hangil Industry Co.). As shown in Table 2, the welding parameters are combined between the weld current (A) and welding speed (rpm). To obtain a full penetration depth of the weld in the weld joint, the weld current should 

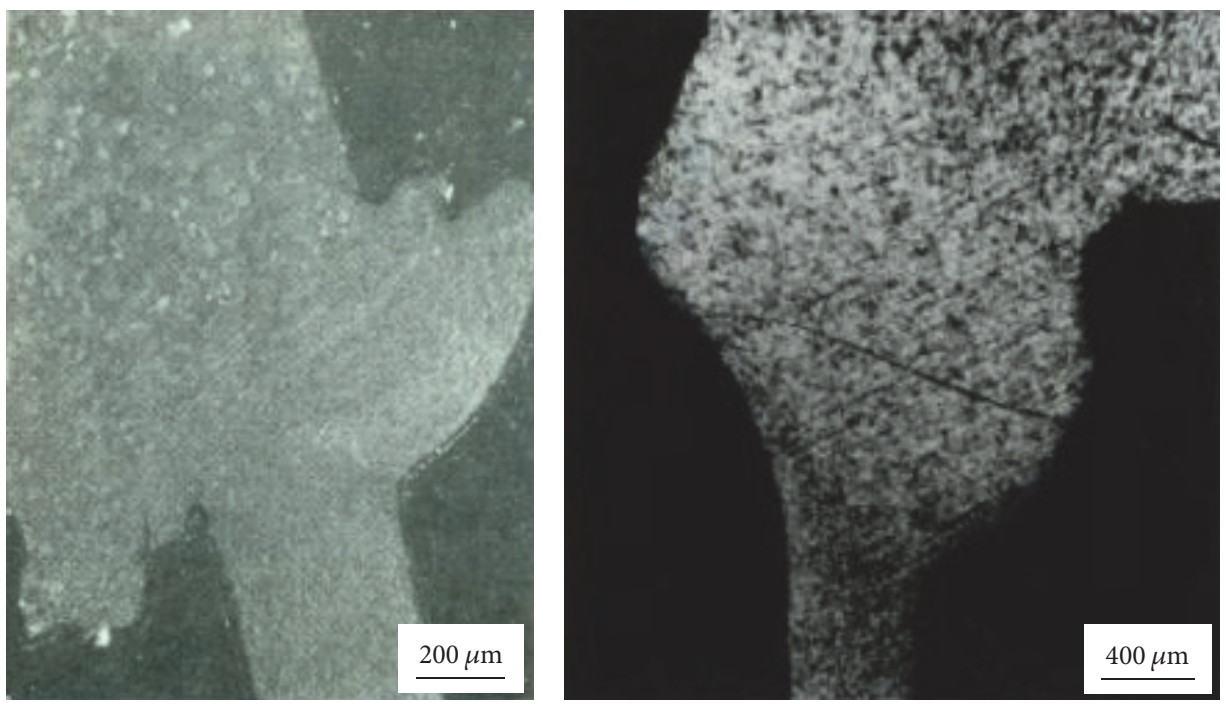

FIGURE 7: Weld shape after resistance welding.

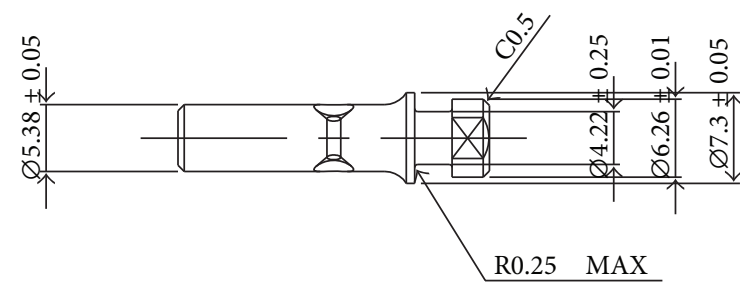

(a) End plug

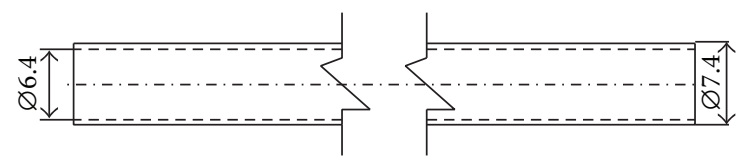

(b) Cladding tube

FIGURE 8: Weld joint design for SFR fuel end plug welding.

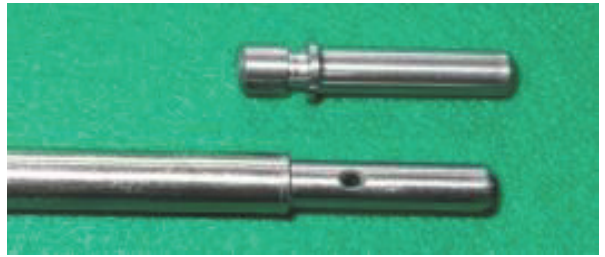

(a) Weld parts

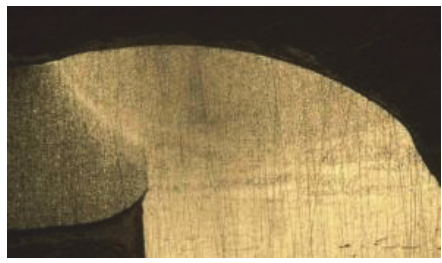

(b) Weld shape

FIGURE 9: Joint parts before welding and weld shape after welding.
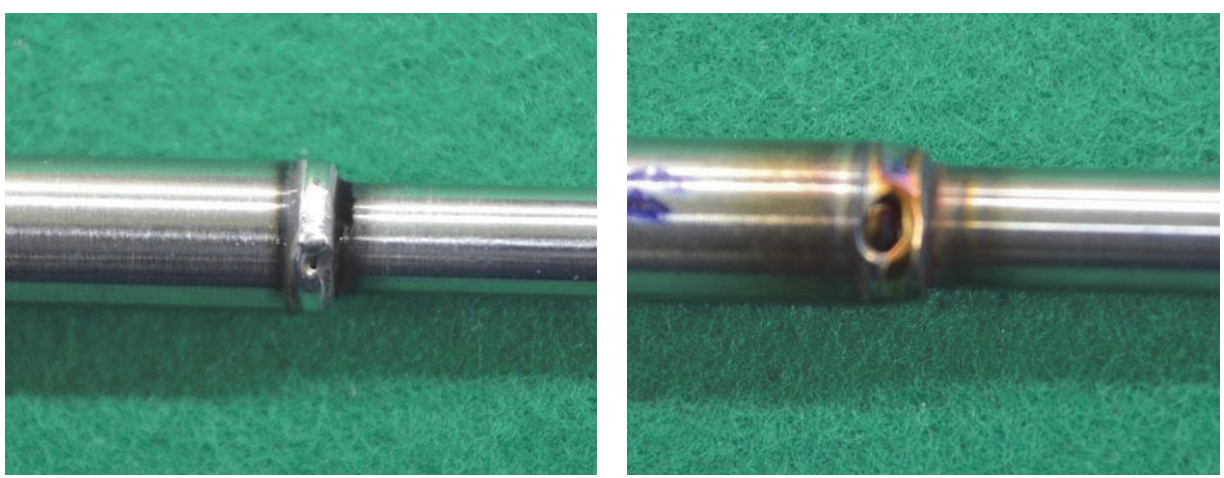

FIGURE 10: Weld defects in the end plug welding. 
TABLE 2: Experimental welding parameters.

\begin{tabular}{|c|c|c|c|c|c|c|}
\hline \multicolumn{2}{|c|}{ Gap } & \multicolumn{4}{|c|}{ Rotation } & \multirow{2}{*}{ Weld current (A) } \\
\hline Volt (V) & Stick-out $(\mathrm{mm})$ & Total $\left({ }^{\circ}\right)$ & Speed (rpm) & Start $\left({ }^{\circ}\right)$ & End $\left({ }^{\circ}\right)$ & \\
\hline 8 & 0.7 & 2000 & 20 & 20 & 460 & 30 \\
\hline 8 & 0.7 & 2000 & 20 & 20 & 460 & 34 \\
\hline 8 & 0.7 & 2000 & 20 & 20 & 460 & 32 \\
\hline 8 & 0.7 & 2000 & 10 & 20 & 460 & 30 \\
\hline 8 & 0.7 & 2000 & 15 & 20 & 460 & 30 \\
\hline 8 & 0.7 & 2000 & 30 & 20 & 460 & 30 \\
\hline
\end{tabular}

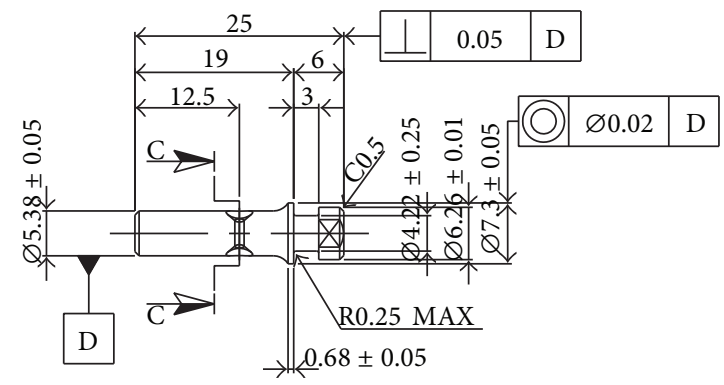

FIGURE 11: Dimensions of the original end plug for welding.

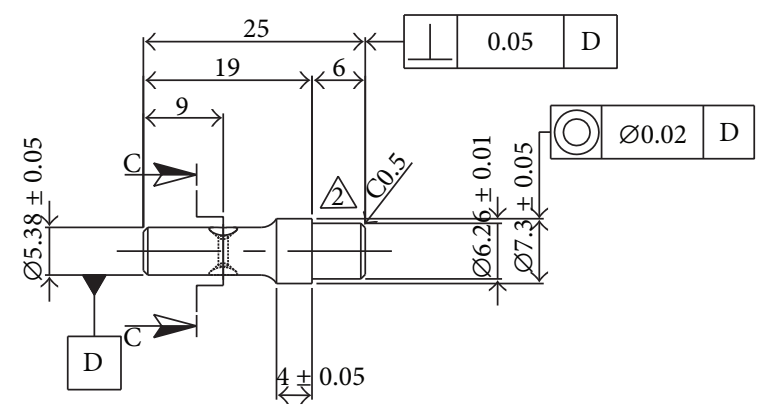

Figure 12: Dimensions of the improved end plug for welding.
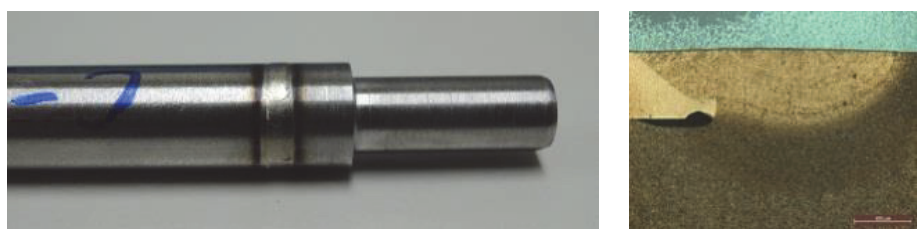

FIGURE 13: Weld shape with the improved weld plug.

be higher than $28 \mathrm{~A}$, while the welding speed should be faster than $30 \mathrm{rpm}$. If the weld current is higher than $32 \mathrm{~A}$, the weld bead in the outer weld shape becomes concave, as shown in Figure 14 .

As a result of the performance welding tests, the optimal welding parameters were established with a weld current of $30 \mathrm{~A}$ and welding speed of $30 \mathrm{rpm}$. With this parameter, a good weld shape and weld quality were obtained, as shown in Figure 13.

\section{End Plug Welding Qualification}

4.1. Qualification Test Plan. The end plug welding of a SFR metallic fuel rod is a special process according to the Quality Assurance Program and domestic regulation, the Korea Electric Power Industry Code (KEPIC). Thus, a qualification test has to be conducted to prove the weld quality of the end plug welding of a SFR metallic fuel rod. The qualification should include the examination and evaluation of the welds 

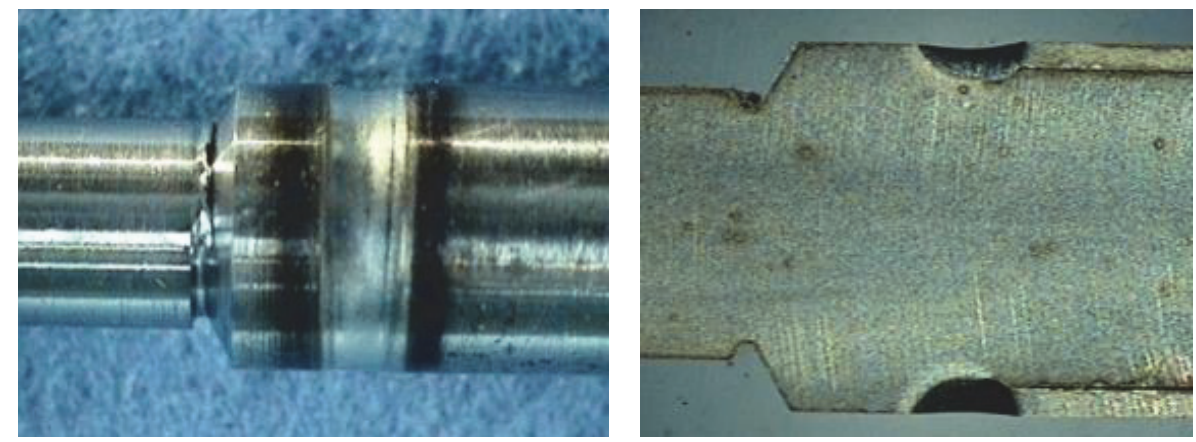

Figure 14: Weld bead shape welded at 35 A-30 rpm.

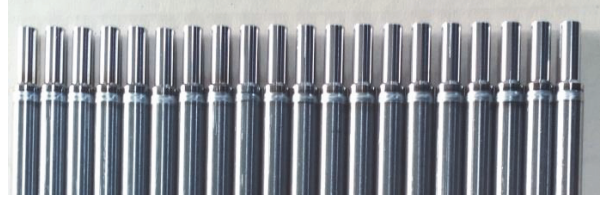

FIGURE 15: Dummy fuel elements welded by GTAW.

made over a range of conditions to establish the lower and upper limits of the welding parameters. The evaluation should include a metallographic examination for the penetration, structure, and lack of voids and cracks. It should also include mechanical property evaluations. The following qualification test plan and procedures were developed based on the QA program used in the commercial fuel fabrication:

(i) Welding 20 dummy fuel elements by GTAW

(ii) Postweld heat treatment $\left(750^{\circ} \mathrm{C}, 20 \mathrm{~min}\right)$

(iii) Visual inspection

(iv) X-ray radiography

(v) Selecting 10 elements for quality evaluation

(vi) He-leak test for 5 elements

(vii) Measuring dimensions for 5 elements

(viii) Analyzing the gas contents purity

(ix) Metallographic examination for 3 elements

(x) Burst test for 3 elements

(xi) Tensile test for 3 elements

For the evaluation of the end plug weld quality, the following criteria were established:

(i) The fabricated fuel elements shall meet all dimensions described in the drawing.

(ii) The end plug to tube weld shall have tensile and burst strengths equal to or greater than those of the tube material.

(iii) The weld joint between the end plug and tube shall consist of sound metal, the effective length of which, in the radial projection, shall be no less than $90 \%$ of the tube thickness. (iv) Fuel elements shall have a filling gas at atmospheric pressure and with a purity of $99.999 \%$ helium.

(v) Fuel elements shall be helium leak tested. All fuel elements showing a detectable helium leak $(>1 \times$ $10^{-7} \mathrm{~cm}^{3} / \mathrm{s}$ ) shall be rejected.

4.2. Qualification Test Results. Based on the developed welding technique, welding equipment, welding conditions, and parameters, 20 dummy elements were prepared using the following welding parameters:

(i) Stick-out: $0.7 \mathrm{~mm}$

(ii) Weld current: $30 \mathrm{~A}$

(iii) Welding speed: $30 \mathrm{rpm}$

According to the qualification test plan and procedures, the weld quality evaluation tests were conducted and the following test results were obtained.

As shown in Figures 15-19, the results of visual inspection, $\mathrm{X}$-ray radiography, metallographic examination, burst test, and tensile test satisfied the quality criteria. No weld defect was in the visual inspection, X-ray radiography, and metallographic examination. The cladding tube part, not weld part, ruptured in the burst test and tensile test. And also any defect was not found in dimension measurements. In addition, no defect was found through a helium leak test. The helium gas filled in an inner space of a fuel rod was analyzed using GasMass Spectrometry. It showed a $99.625 \%$, mole fraction of the He content. As a result of the qualification test, the weld quality of the end plug welding of the SFR metallic fuel rod was qualified, and the welding process is ready to produce SFR metallic fuel rods under the qualified conditions. 


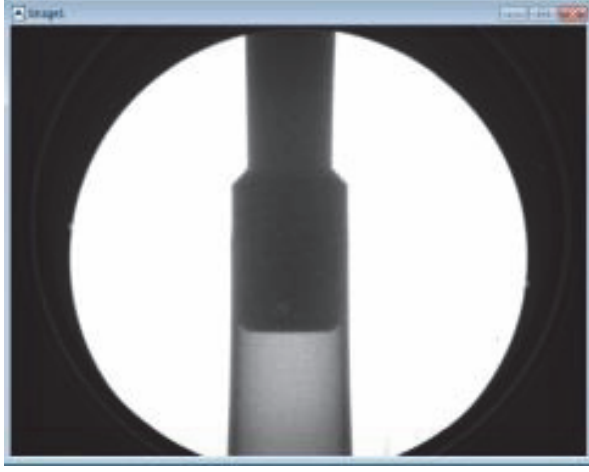

(a) X-ray result

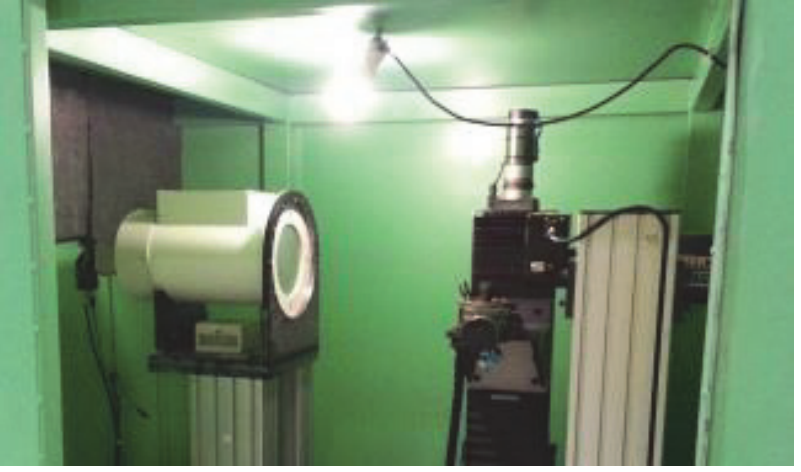

(b) X-ray radiography

FIGURE 16: X-ray radiography on the weld part.
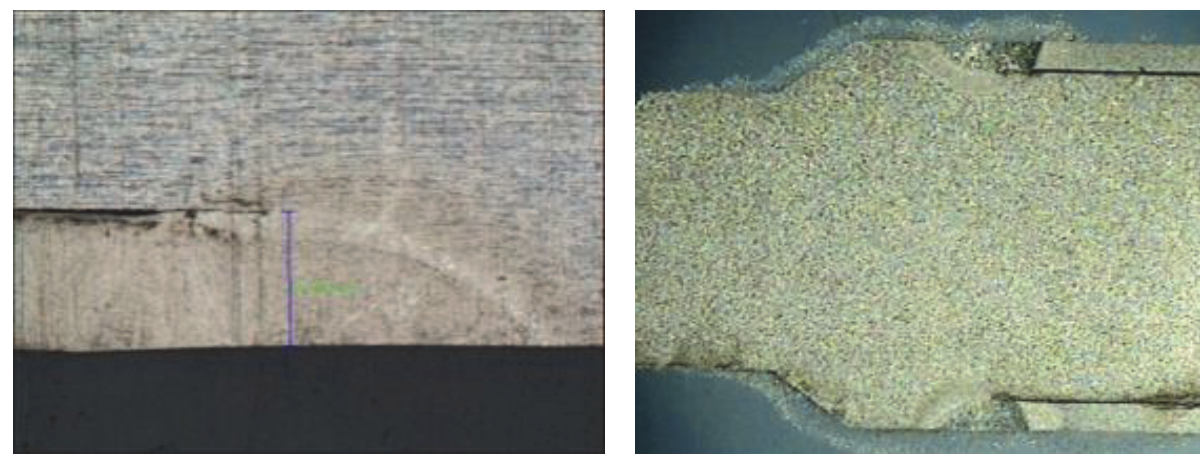

FIGURE 17: Metallographic examination result on the weld part.

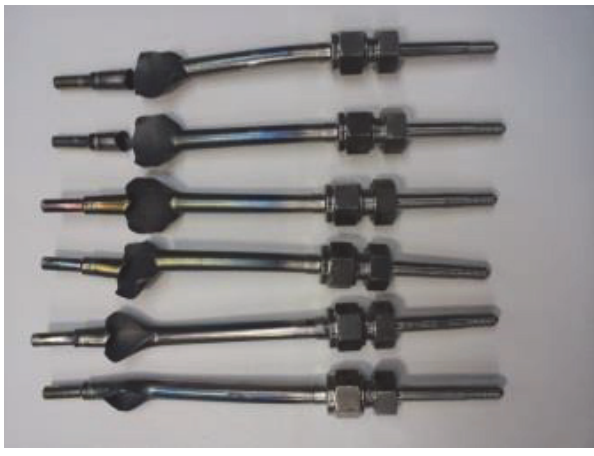

(a) Burst test result

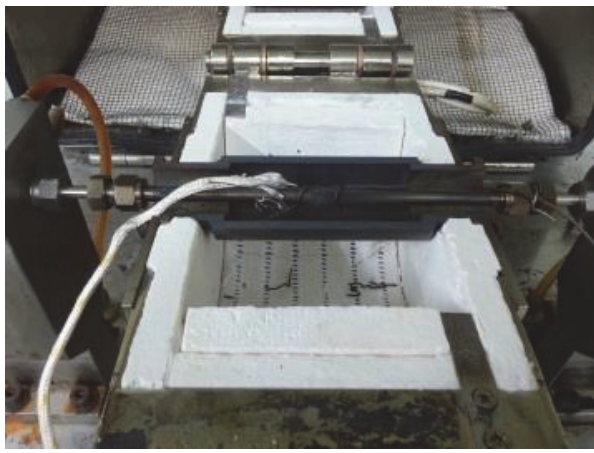

(b) Tube burst tester

Figure 18: Burst test of fuel elements.

\section{Conclusions}

Through a series of welding experiments, the weld joint design, welding conditions, and parameters were developed for the fabrication of SFR metallic fuel rods by GTAW. Based on the results of these experiments, a weld qualification test was conducted and the weld quality of the end plug welding was evaluated according to the qualification test plan. The qualification test results satisfied the requirements of the end plug weld of a SFR fuel rod. Consequently, the qualified welding process is ready to produce SFR metallic fuel rods.

\section{Competing Interests}

The authors declare that there are no competing interests regarding the publication of this paper. 


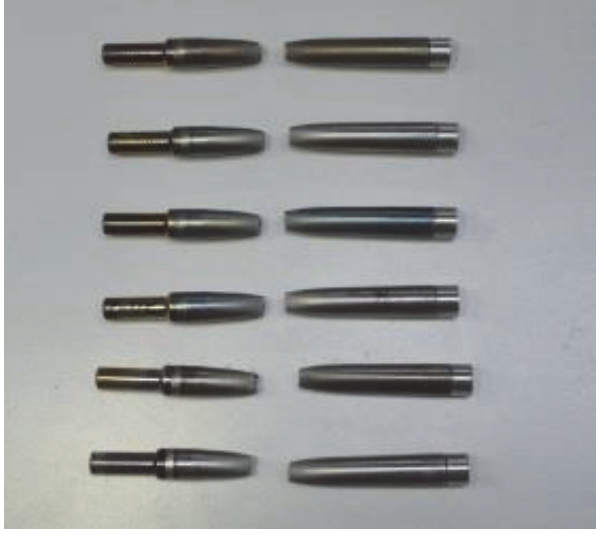

(a) Tensile test result

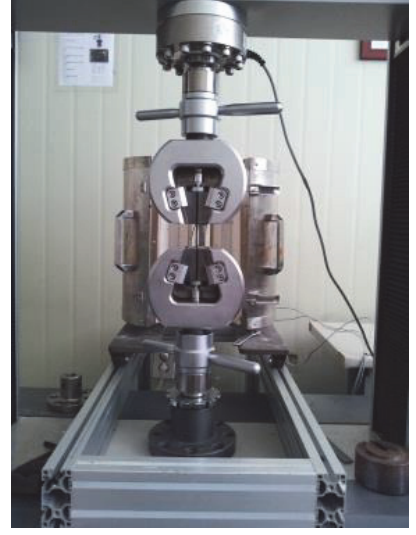

(b) Tensile tester

FIGURE 19: Tensile test of fuel elements.

\section{Acknowledgments}

This work has been carried out under the Nuclear Research and Development Program supported by the Ministry of Science, Ict and Future Planning in the Republic of Korea. The authors would like to thank Mr. Hyung Tae Kim for his help and contributions in the metallographic examination.

\section{References}

[1] J. E. Kelly, "Generation IV International Forum: a decade of progress through international cooperation," Progress in Nuclear Energy, vol. 77, pp. 240-245, 2014.

[2] K. Aoto, P. Dufour, Y. Hongyi et al., "A summary of sodiumcooled fast reactor development," Progress in Nuclear Energy, vol. 77, pp. 247-265, 2014.

[3] F. Delage, J. Carmack, C. B. Lee, T. Mizuno, M. Pelletier, and J. Somers, "Status of advanced fuel candidates for sodium fast reactor within the generation IV international forum," Journal of Nuclear Materials, vol. 441, no. 1-3, pp. 515-519, 2013.

[4] T. Bates, "Resistance welding of zircaloy end closure joints," Tech. Rep. AECL-2814, Atomic Fuel Department, Port Hope, Canada, 1996.

[5] L. E. Mills, "Zircaloy welding techniques developed for plutonium recycle program $\mathrm{UO}_{2}$ fuel element fabrication," Tech. Rep. HW-66178, Hanford Atomic Products Operation, Richland, Wash, USA, 1960.

[6] S.-S. Kim, G.-I. Park, J.-W. Lee, J.-H. Koh, and C.-H. Park, "Effect of heat on the soundness of zircaloy-4 end cap closure using a resistance upset welding," Journal of Nuclear Science and Technology, vol. 47, no. 3, pp. 262-268, 2010.

[7] J. W. Lee, S. S. Kim, Y. M. Woo, H. T. Kim, K. H. Kim, and K. H. Yoon, "Weld joint design for SFR metallic fuel element closures," in Proceedings of the KNS Spring Meeting, Jeju, Korea, 2014.

[8] Y. Chen, "Irradiation effects of HT-9 martensitic steel," Nuclear Engineering and Technology, vol. 45, no. 3, pp. 311-322, 2013. 

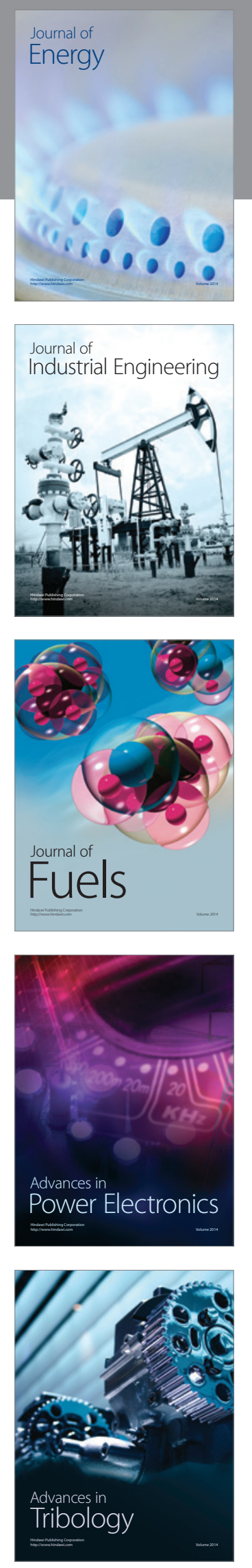
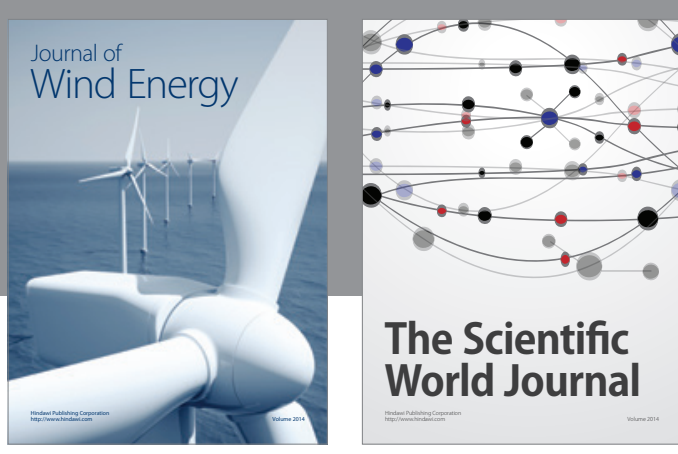

The Scientific World Journal
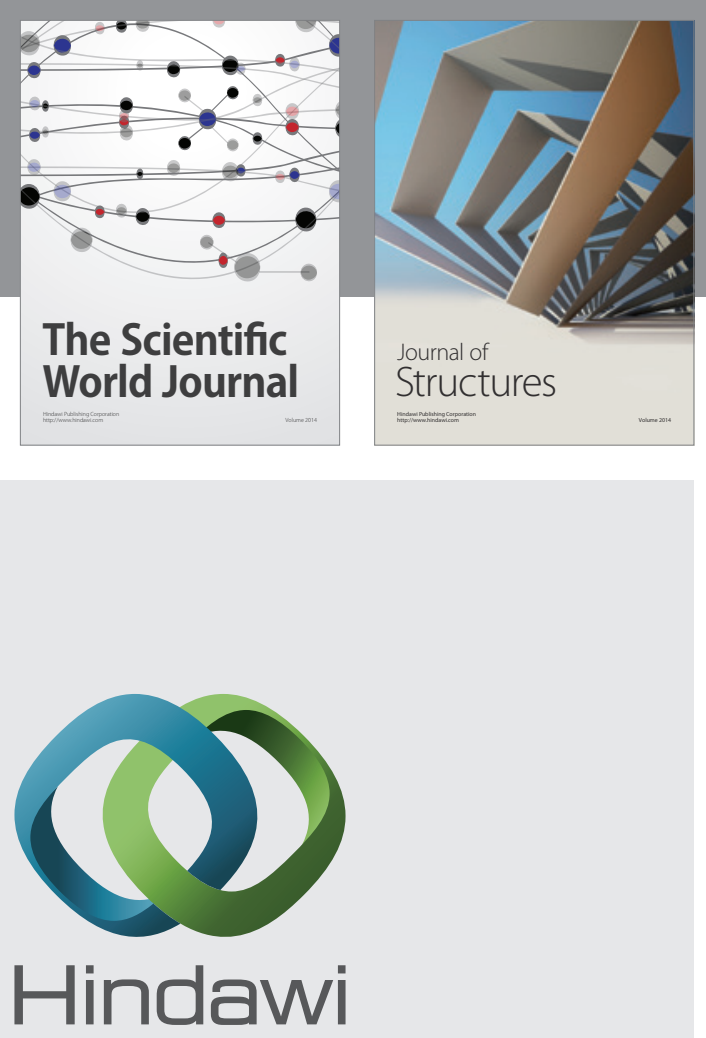

Submit your manuscripts at

http://www.hindawi.com
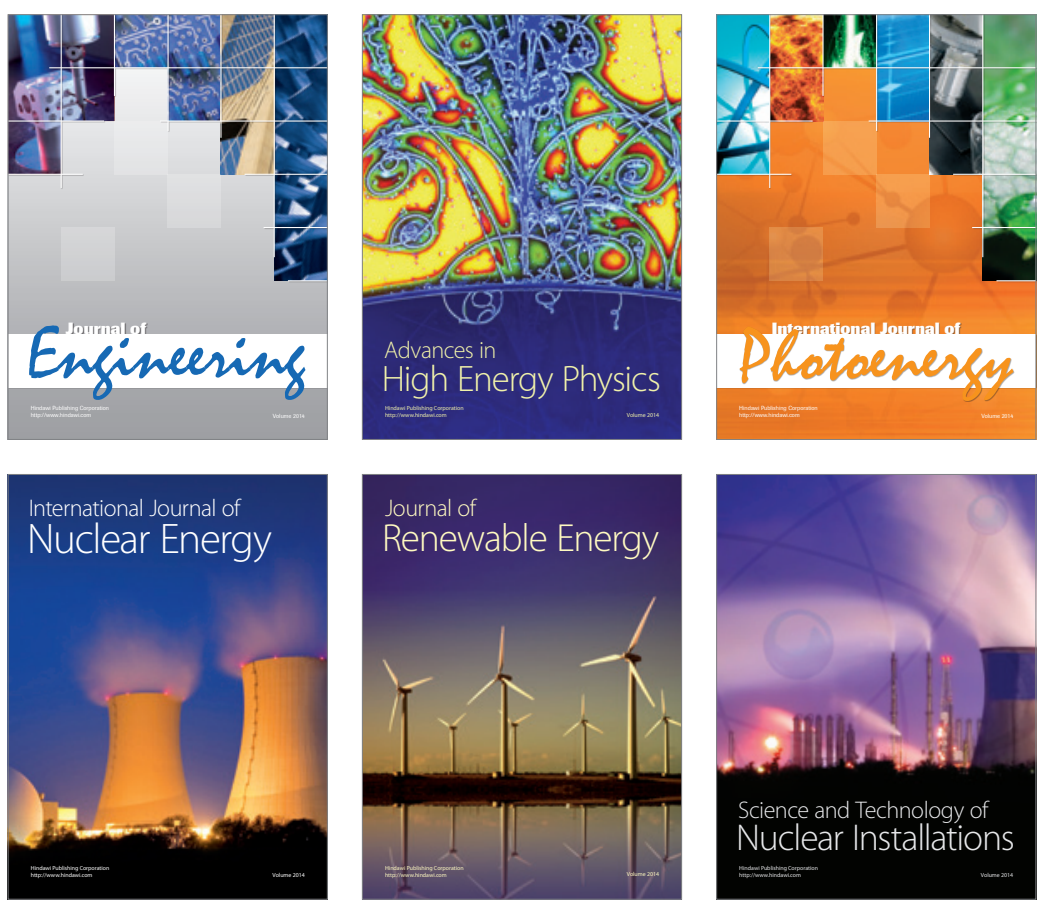
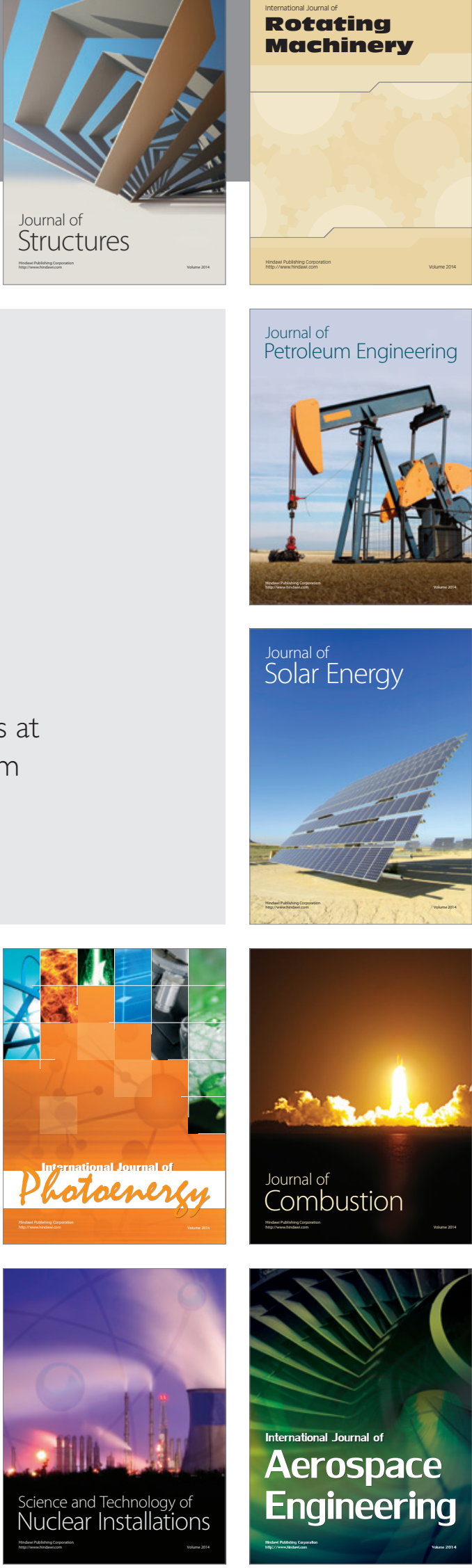